\title{
技術解説
}

\section{アナログコンポーネント \\ 新しい時分割多重カラーテレビ方式}

正会員 石 田 順 - $^{\dagger}$

\begin{abstract}
テレビ放送局の局内設備や放送には，NTSC コンポジット信号方式が用いられているが，最近 になって衛星放送用として TCI，MAC などと呼ばれるアナログコンポーネント信号方式が話題に のぼるようになった．また，局内設備にこの方式を導入することも提案されている．ここではアナ ログコンポーネント方式が導入されるようななった経緯，その特徵などについて解説する.
\end{abstract}

\section{1. まえ がき}

BS-2 による衛星放送が始まり，我が国もいよいよ 衛星放送の実用化の時代を迎えた。欧米でも同様な直 接放送衛星打上げの計画があるが，イギリスでは CMAC 方式を用いて放送することが報じられている． また, 我が国でも将来, 高品位テレビを MUSE 方式 により衛星放送することが考えられている。これらの 信号方式は, いずれもテレビの輝度信号と色信号を時 分割多重伝送するものであり，時分割多重アナログコ ンポーネント方式と総称されている.

従来の NTSC 方式は, 周知のとおり輝度信号に色 信号を副搬送波を用いて周波数多重するコンポジット 信号方式であるが，後述するようにいくつかの欠点も あり, 最近の技術には不都合な面も出て来ている. 本 稿では, アナログコンポーネント方式がどういう理由 で導入されるようになりつつあるか，またどういった 特長があるかについて解説する。

なお，アナログコンポーネントという名前は，もと からあったわけではない。最初は CCIR でディジタル テレビの符号化規格を決めるに当たって, $\mathrm{Y}, \mathrm{R}-\mathrm{Y}$, B-Y のコンポーネント信号を個別にディジタル化す ることが原則とされた ${ }^{1)}$ (その際, 標本化周波数を 13 . $5 \mathrm{MHz}$ と $6.75 \mathrm{MHz}$ にすることが決められたことは 周知の通りである).そして, このディジタルコンポ ーネント符号化方式に対応して, アナログコンポーネ ントの名がつけられたものである.

$\dagger \mathrm{NHK}$ 技術本部

“Analog Components: A New Time-Multiplexed Color Television Signal Format" by Junichi lshida (Engineering Headquarters, NHK, Tokyo)

\section{NTSC 方式の問題点}

NTSC 方式は 1953 年に米国の NTSC（National Television System Committee) で決められたもので ある．その当時，米国のカラーテレビ標準方式決定に 際して, CBS のフィールド順次方式との間に論争が あり，いったん FCC が CBS 方式を採用したのにも かかわらず， RCA をはじめとする工業会の反対によ って再度 NTSC 方式に軍配があげられたことは, 昔 の語り草になりつつある.日本では, 1960 年に NTSC 方式を標準方式とすることを決めている.

NTSC 方式は，現在の技術で考えても非常に巧妙 な方式であって，当時放送されていたモノクロテレビ とはほとんど完全な両立性を保ちつつ, 現在でもたい ていの画面については充分満足できる画質が得られて いることは，驚異的であるとさえいえる．

しかし, NTSC 方式にはいくつかの欠点もある.

\section{1 輝度信号と色信号間のクロストーク}

欠点の第 1 は，輝度信号と色信号は図 1 のように周 波数インターリーブしているといっても, 画像の垂直 方向高周波成分によるスペクトルの重なり合いによ り,クロストークを生ずることである．例えばシャツ

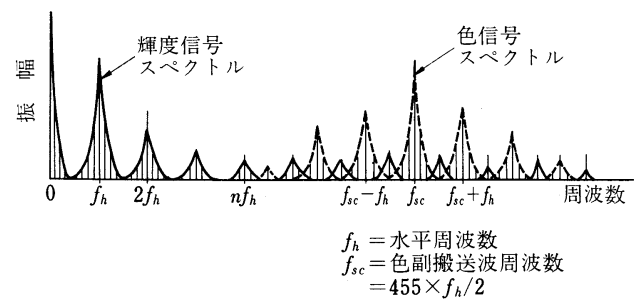

図 1 NTSC 信号の周波数スペクトル テレビジョン学会誌 Vol. 39, No. 2 (1985) 
の縞模様のように，輝度の細かい斜め成分ではクロス カラーを生じ, 画像のエッジ部などではクロスルミナ ンスを生ずる．特にクロスカラーによる妨害は大き く, 対策としては, 出演者に縞の服を着ないようにし てもらう, カメラをデフォーカスする, 縞の周波数が $3.58 \mathrm{MHz}$ から離れるようにズーミングするなどの消 極的方法しかなかった(この対策として放送局側でく し形フィルタを入れている局もある)。

一方, 受信機側では, 輝度信号と色信号の分離にく し形フィルタを用いる必要があるが, 従来は受信機コ ストを下げるため, 輝度信号は $2.5 \mathrm{MHz}$ 位の LPF, 搬送色信号は $3.58 \pm 0.5 \mathrm{MHz}$ の BPF で抜き出すとい う簡単な方法が用いられ，輝度信号の高域成分は有効 に利用されていない。これは, 最近のテレビカメラの 高品質化に対して，画質の制約を与えるだけでなく， 品質の向上がかえってクロスカラーを増やすだけとい う皮肉な結果にもなっている．最近になってようやく AV (Audio-Video) テレビなどと称する，くし形フィ ル夕を用いた受信機も出て来たが，まだ全体から見る とごく一部に過ぎない*.

\section{2 伝送路特性への要求のきびしさ}

NTSC 方式の第 2 の欠点として, 伝送系の特性保 持に対する要求がきびしくなるという点があげられ る. 伝送路の直線ひずみに関しては, 輝度信号と色信 号の相対レベル比を一定に保つため高い周波数まで平 担な振幅特性が必要であり, マルチパス妨害などに弱 いという問題がある。また, 両信号間の時間差を生じ ないよう群遅延時間も小さくおさえる必要がある. 非 直線ひずみに関しては DG・DP 特性への要求がきびし く, その他の輝度信号と色信号の相互変調ひずみが問 題となることもある(PAL, SECAM 方式は NTSC 方式に比べ非直線ひずみの影響が少ないが, その分, 輝度信号と色信号間のクロストークが大きくなるとい うペナルティーを負っている)。また，VTR の開発 初期には, 再生信号のジッ夕による色むらの問題があ ったが,これはタイムベースコレクタの考案により解 決された。

\section{3 ディジタル信号処理への不適合性}

NTSC 方式の第 3 の欠点は, 最近のディジタル技 術を用いた種々の信号処理において, 不都合を生ずる ということである. ディジタル信号処理では, ディジ タルメモリーを利用して, 従来のアナログ信号処理で は難かしかった時間軸処理が非常に多く行われてい る.その例としては, フレームシンクロナイザやノイ

\footnotetext{
*クロスカラーはライン型くし形フィルタでも取れず, 後述する フレーム型くし形フィルタを用いてはじめて取れる。
}

ズリデューサ，ディジタル特殊効果(DVE)などがあ げられる。

これらの機器は, アナログの海の中のディジタルア イランドという形で用いられるため, 当然 NTSC 信 号を扱わねばならないが，メモリーを用いて種々の時 間軸処理を行うとき, NTSC 信号の色副搬送位相は 同期信号に対してオフセット関係にあるため，4フィ ールドシーケンスの問題など, いろいろと具合の悪い ことが起こって来る.

例えば，ノイズリデューサで連続する 2 フレーム間 の信号の加算をしようとしても，搬送色信号について は副搬送波の位相が $180^{\circ}$ 反転しているため, 引算に なってしまう。また, 特殊効果においても, 画面の拡 大や縮小を行おうとすると, 色副搬送波周波数が変わ ってしまう。したがって,これらの信号処理を行うと きには, NTSC 信号を YC 分離して, 輝度信号と色 信号のコンポーネント信号に変換し, 信号処理を終っ てから再び NTSC 信号にエンコードする方法がとら れている。

しかし,これらの信号処理のたびに YC 分離と， NTSC エンコードを繰り返すことは, 今後ますます このような信号処理が増えることを考えると，画質劣 化が問題となり，回路構成上でも不経済である，そこ で, 後に述べるように, スタジオ内ではコンポーネン 卜信号を用いるという考えも出始めている.

\subsection{FM 伝送への不適合性}

NTSC 方式は, もうひとつ, FM 伝送では伝送効 率が低下するという欠点がある。衛星放送では, 衛星 重量や太陽電池出力が制限され, 衛星送信出力も制限 されるためと, 小口径の受信アンテナで良好な SN 比 を得るため, 広帯域利得のとれる FM 伝送方式が用 いられるのが普通である.また, 送信用 TWTを効 率良く使うという面からも, 搬送波振幅一定の FM 方式の方が都合が良い.

この FM 伝送において，NTSC 方式は次のような マイナス面を持っているＦM 伝送では，周知のよう に復調器出力雑音は図 $2(\mathrm{a})$ に示す三角形のスペクト ルを持つ, いわゆる三角雑音になるが, FM-NTSC 信号を復調して, YC コンポーネント信号にデコード した後の雑音スペクトルは図 2 ( b ) のようになる.

この図でわかるように, 搬送色信号は三角雑音の最 も大きい高域に多重されているため, 雑音妨害を大き く受ける. 一方, 視覚の雑音妨害に対する周波数ウエ イティング特性は，いわゆるLPF 型になっており， 雑音の低域成分ほど目立ち易く, 高域ノイズは目立ち にくいため, 輝度信号に混入した三角雑音から受ける 


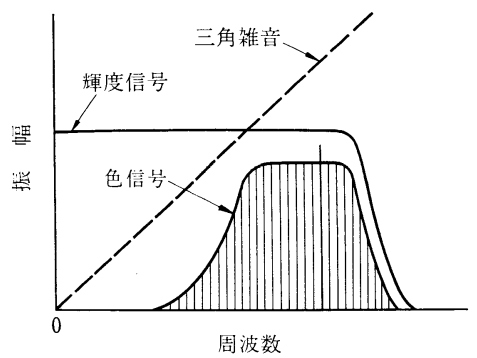

(a) NTSC 信号と三角雑音のスペクトル

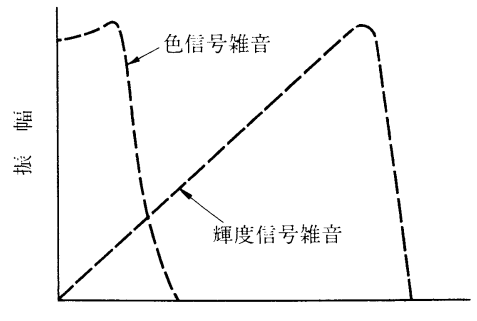

周波数

(b) NTSC 信号復調後の雑音スペクトル

図 2 NTSC 信号の FM 伝送雑音

妨害は小さい。この点で FM 伝送はモノクロ信号の ようなベースバンドテレビ信号の伝送には, 非常に適 したものになっている*.

しかし, NTSC 信号の色信号チャンネルでは, 三 角雑音の最も大きい部分が最も目立ちやすい低域ノイ ズに変換されるため, 雑音妨害を大きく受ける，この ように, NTSC 信号の FM 伝送では, 輝度信号チャ ンネルと色信号チャンネルの評価 SN 比に大きなアン バランスを生じるため, 伝送効率が低下してしまう.

このような問題を避ける方法として, 次章に述べる TCI や MAC と呼ばれるアナログコンポーネント方 式が考えられた。な拉, 我が国に打ける衛星放送に NTSC 方式が用いられているのは, 現行地上放送受 信機との両立性を優先的に考えたためであって，ITU による衛星チャンネル割当ても，コンポジット信号伝 送を基準として決められている。

\section{FM 伝送用アナログコンポーネント方式}

前章で, FM 伝送方式はベースバンドテレビ信号の 伝送に非常にマッチした方式であることを述べた。こ の点に着目したのが，次に述べる時分割多重アナログ コンポーネント方式である。この方式では，図 3 のよ うに, 輝度信号と色信号を時間圧縮して1ライン上に

* 白黒画像の白色雑音と三角雑音に対するウェイティング値の差 は $8 \mathrm{~dB}$ に達する。

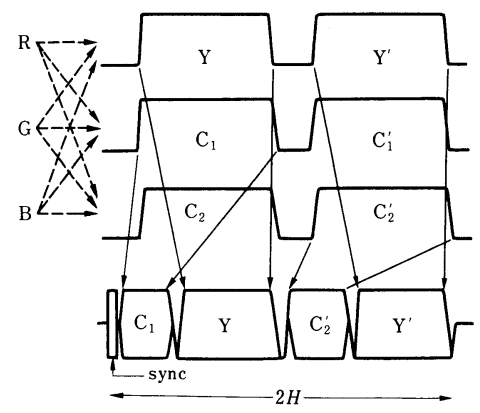

図 3 時分割多重アナログコンポーネント信号形式

時分割多重して伝送する．2つの色信号は線順次方式 で伝送される．この方式は，以前にモノクロフィルム にカラー画像を記録する方式として考案されたもので あるが ${ }^{3)}$, 最近になってほぼ時を同じくして, 日本で は高品位テレビの衛星伝送用 TCI 方式として, 英国 では 625 本方式 DBS (Direct Broadcast Satellite) 用 の MAC 方式として独立に発表された.

アナログコンポーネント方式では, 前章に述べた NTSC 方式の問題点がほとんどすべて解決される. この方式の欠点といえば, 信号の多重時の時間圧縮と デコード時の時間伸長に, 今のところディジタル技術 を用いざるを得ず，そのために $\mathrm{AD}$ コンバータ， $1 H$ メモリー, DA コンバー夕をそれぞれ必要とすること である.しかし最近では， AD コンバータも 1 チップ のモノリシックタイプが市販されており，コストの問 題も解決されるであろうし, 将来は CCD も利用でき るようになるだろう。この他に, デコーダ側では, メ モリー書込み・読出しのための正確なタイミングのク ロック再生技術も重要である.

時分割多重信号では, 時間圧縮によりもとのベース バンド信号より帯域が広がるため, 同一 FM 伝送帯 域での FM 改善度は低下するが, 色信号チャンネル の雑音妨害が減少するため, 全体としてはかえって伝 送効率が向上するという計算になる。また，NTSC 方式のような DG, DP の問題がないので, エンファ シスにより，低域の周波数偏移を下げる必要はなく， むしろ非直線ひずみに強いという点を生かして, 非直 線エンファシスなどを用いて, 積極的に SN 比の改善 を行うことができる. 輝度信号と色信号の時間圧縮比 は, 輝度信号と色信号の帯域幅の逆比近くにとり, 圧 縮後の信号帯域がほぼ等しくなるようにする.

この場合, 色信号チャンネルでは, 復調後時間伸長 により雑音スペクトルが低域に圧縮される程度が大き いため視覚的に妨害度が大きくなるが, 輝度雑音と色 雑音に対するウェイティングの差があるため, ほぼ輝 


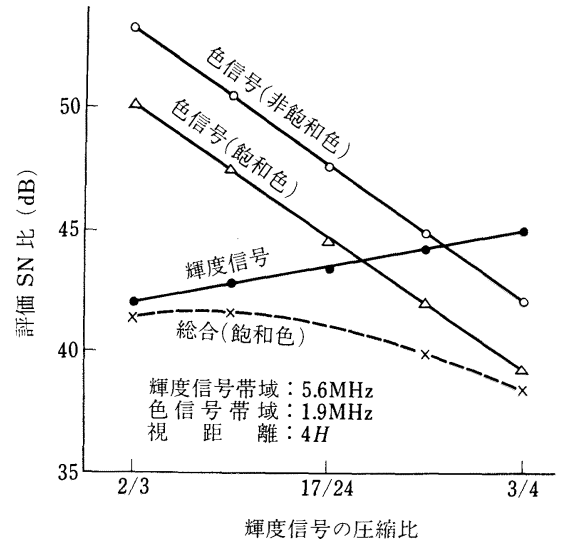

図 4 輝度信号の圧縮比と $\mathrm{SN}$ 比の関係

度信号チャンネルと色信号チャンネルの評価 $\mathrm{SN}$ 比が バランスするようになっている。

図 4 は, 525 本方式で輝度信号と色信号の時間圧縮 比を変えたときに, 両チャンネルの評価 SN 比がどの ように変化するかを示したものであるが ${ }^{4)}$, その変化 はあまり急峻ではない。したがって，むしろ圧縮比を 簡単な整数比にして, 時間圧伸用メモリ一駆動クロッ クの発生が容易にできるようにした方が良い.

\subsection{TCI 方式}

TCI 方式は, Time Compressed Integration の略 で, 高品位テレビの衛星伝送用に考えられた ${ }^{5)}$. TCI エンコーダとデコーダの構成を図 5 に示す. RGB 信 号は, マトリックス回路で輝度信号 Y と2つの色信 号 $\mathrm{C}_{\mathrm{w}}, \mathrm{C}_{\mathrm{N}}\left(\mathrm{C}_{\mathrm{w}}\right.$ : 広帯域軸信号, $\mathrm{C}_{\mathrm{N}}$ : 狭帯域軸信号) となり, 各々 $\mathrm{AD}$ コンバータでディジタル信号に変 換される。

ここで注意を要するのは, 色信号の帯域制限フィル 夕の特性で, 色信号のリンギングは非常に目立つので シャープカットオフのフィルタを用いることはでき ず，あまりスローロールオフのフィルタでは折返しひ ずみが生じる，ここでは，矩形波応答のオーバシュー トを $5 \%$ におさえた図 6 の特性のフィル夕を用いてい る).

ディジタル化された色信号は, 線順次信号に変換す る前に垂直方向の LPF に入る.これは, 図7 のよう に走査線による画面のサンプリングが行われ，さらに 線順次信号とするときに走查線の間引き (サブサンプ リング)により折返しひずみが生じないようにするた めである.フィルタには，7タップのトランスバーサ ル型 (1 次バターワース)が用いられ，2つの色信号を 時分割多重することにより1個のフィル夕を共用して いる.

帯域制限された色信号は走査線 1 本毎に間引きし

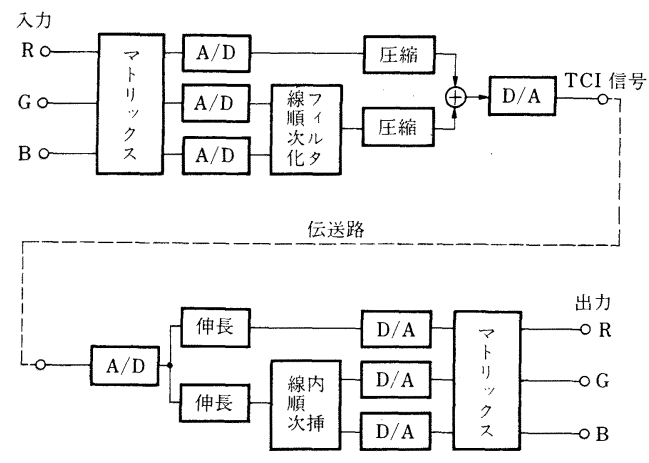

図 5 TCI エンコーダとデコーダの構成

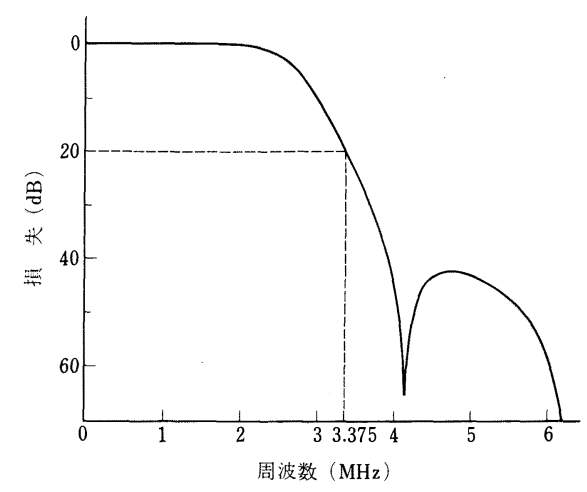

図 6 コンポーネント色信号用フィルタの特性

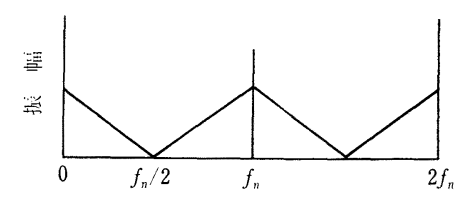

(a) 原湖等スヘクトル

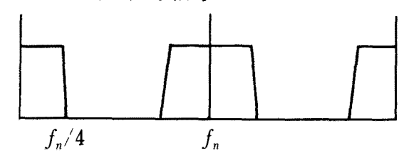

(b) 前置フィルタ

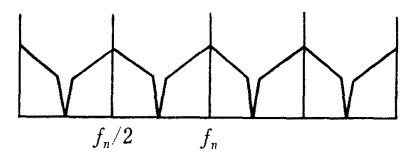

(c) 線㮌次俭号スペクトル

$f_{n}:$ 走㜀線数

図 7 線順次信号のスペクトル

て, $1 H$ メモリーに書込み, 読出しタイミングを変え ることにより，時間軸圧縮と時間軸上のシフトが行わ れる. 線順次切換用のラインスイッチは, フレームリ セットをしないと, あるラインでフレームごとに $\mathrm{C}_{\mathrm{w}}$ と $\mathrm{C}_{\mathrm{N}}$ 信号が交互に送られるようになるので, 残留折 


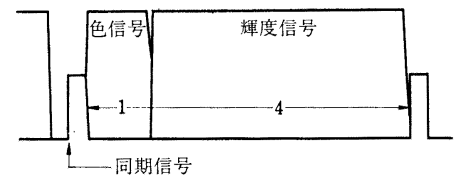

図 8 TCI-MUSE 信号波形

返しひずみによるちらつきを避けるためには，フレー ムリセットを行った方が良い。

なお，色信号は垂直フィルタで $3 H$ 遅れるので, その分 Y 信号を遅らせておく必要があるが，デコー ダ側でも同様の遅れを生ずるので，Y 信号をその分 を含めて遅らせておいた方が，デコーダが簡単にな る. Y 信号は, 時間圧縮を行わず, ブランキング期 間を $25 \%$ とって，そこに色信号を $1 / 4$ に時間圧縮し て時分割多重している.

デコーダ側では，逆の操作を行って $\mathrm{Y}, \mathrm{C}_{\mathrm{w}}, \mathrm{C}_{\mathrm{N}}$ コ ンポーネント信号が復元される. 線順次色信号の内挿 用垂直方向フィル夕は，簡易化のため 3 タップのフィ ル夕を用いている。 また DA 変換後の内挿フィルタ には，エンコーダフィルタの $40 \mathrm{~dB}$ 減衰周波数でシ ヤープカットオフする特性を持たせている．

高品位テレビの TCI 信号波形を図 8 に示す. 同期 信号は正極同期となっており, それだけ FM の周波 数偏移を大きくとれるようになっている.また, 信号 中には, 輝度信号と色信号の黒レベルを示すぺデス夕 ルレベルが挿入されている。

この信号を衛星伝送するときには,さらに MUSE 方式(Multiple Sub-Nyquist-sampling Encode) と呼 ばれるフィールド間およびフレーム間オフセットサブ サンプリング技術を用いて, 信号帯域 $8 \mathrm{MHz}$ まで帯 域圧縮を行う7). $8 \mathrm{MHz}$ のベースバンド信号が, 27 $\mathrm{MHz}$ の衛星放送用 1 チャンネル分の帯域で伝送でき るのは, アナログコンポーネント方式の効果である.

\section{$3.2 \mathrm{MAC}$ 方式}

次に英国の IBA から提案された MAC 方式につい て述べよう ${ }^{899)}$. 英国の DBS は 1986 年に打上げられ る予定になっていたが, これに対して, BBC が Extended PAL 方式, IBA が MAC 方式を提案し た.

これらはいずれも現在のPAL 方式における NTSC 方式と同様の欠点を除くために考えられたもので, MAC はアナログコンポーネント方式, Extended PAL は，図9のように輝度信号と色信号の周波数多 重域を分離したコンポジット方式である ${ }^{10)}$. 後者は, 現行受信機に対して両立性を持つ利点があり，どちら を標準方式として採用するかは政府の諮問するパート

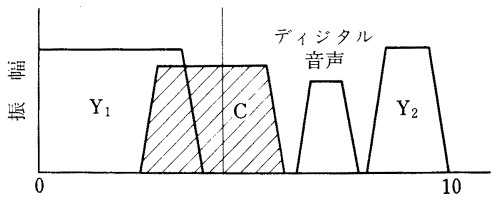

周波数 $(\mathrm{MHz})$

図 9 Extended PAL 信号のスペクトル

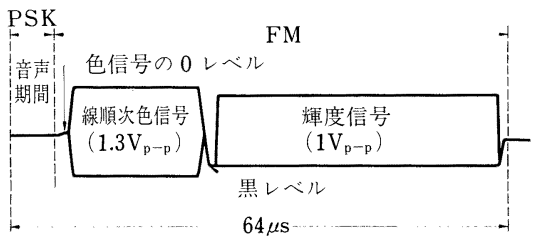

図 $10 \mathrm{MAC}$ 信号波形

委員会の決定に託されることになり, 最終的には技術 的な性能において優れ, 将来の拡張性もある MAC方 式が採択された ${ }^{11)}$.

結局，英国の DBS 計画は，このような経緯のもと で遅れ，放送開始は 1988 年にずれ込みそうな情勢で ある。

MAC 方式は, その後, 西ヨーロッパにおける統一 方式として $\mathrm{EBU}$ (ヨーロッパ放送連合)で検討が行わ れ，C-MAC/Packet 方式がまとめられたが ${ }^{12)}$, 政治 的な事情もあり，まだ全体的なコンセンサスを得るに は至っていないようである. EBU で MAC 方式を採 用したときに得られるメリットは，PAL-SECAM の 両 625 本方式圈を同一の信号でカバーすることができ るようになることで，ヨーロッパのように国が接して いる所では当然衛星からのスピルオーバがあり，これ を共通の受信機で見ることができる．しかし，政治的 には逆にこの点が問題になっているともいえる。

MAC 方式の信号波形は図 10 のとおりで，TCI 方 式と似ている。輝度信号と色信号の帯域幅は 5.6 $\mathrm{MHz}$ と $1.6 \mathrm{MHz}$ で, 時間圧縮比はそれぞれ $2 / 3$ と $1 / 3$ である. 時間圧縮後のベースバンド信号帯域は $8.4 \mathrm{MHz}$ になる.

MAC 方式では, 将来の拡張型として ExtendedDefinition MAC 方式も考えられている ${ }^{13)}$ 。これは日 本の高品位テレビに対する対抗案として考えられたも ので, 輝度信号帯域を $8 \mathrm{MHz}$ (圧縮信号で $12 \mathrm{MHz}$ ) まで拡張するとともに，受信機側でインタレース信号 を順次走査信号に変換して表示することにより，垂直 解像度の改善をはかっている ${ }^{14)}$. また, アスペクト比 を $5: 3$ とするため, 図 11 のように付加情報をブラン 


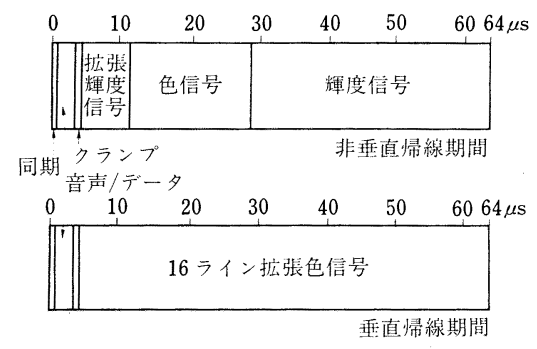

図 11 E-MAC の信号波形

キング期間に挿入している.

\section{3 音声伝送方式}

ここで本題より少しはずれるが, テレビ衛星放送の 音声伝送方式にふれておくことにする。我が国では音 質のすぐれた PCM 周波数多重方式が選ばれている が15), ヨーロッパでは高品質音声への要求のほかに, 多言語放送への要求が(特に北欧諸国で)大きい. MAC の音声多重方式としては $\mathrm{A} ， \mathrm{~B}, \mathrm{C}$ の 3 方式が 考えられ，いずれも PCM 方式で，A-MAC は副搬送 波周波数多重方式，B は PCM ベースバンド時分割多 重方式(いわゆるサウンドインシンク方式), C-MAC は図 10 のような $\mathrm{RF}$ 時分割多重方式である.

$\mathrm{C}$ 方式の特長は多くの音声チャンネルがとれること で, 時分割多重ではチャンネル間隔を時間軸上でせま くとれるのに対し, 周波数多重では周波数軸上でチャ ンネル分離用の急峻なフィルタを得るのが困難なた め, チャンネル間隔をつめることができない. B 方式 との比較では， 2 值伝送では両者の差はほとんどない が, C 方式では 4 相 PSK が使えるため伝送容量が約 2 倍とれる. 4 相 PSK の 2 相 PSK に対する CN 増 は $3 \mathrm{~dB}$ ですむが， B 方式で 4 值伝送を行うと $\mathrm{CN}$ 増 が $6 \mathrm{~dB}$ となって, 映像信号の所要 $\mathrm{CN}$ とのバランス が悪くなってしまう。

C 方式の短所は, 送信側で別の変調器を必要とし, 受信側では 4 相 PSK の復調器やキャリヤ再生回路な ど, 回路が複雑になることである。また，CATV な どでベースバンド伝送ができないという問題もある.

高品位テレビ用 TCI 方式では, 周波数帯域, 水平 帰線期間とも余裕がないため, 垂直帰線期間に音声信 号を 4 相 PSK で時分割多重している.

\section{4. スタジオ用アナログコンポーネント方式}

現在のテレビ番組の制作システムは, ほとんど NTSC 方式で構成されている.しかし， 2 章で述べ たように，ディジタル技術を用いた複雑な信号処理が 行われるようになり，NTSC 信号形式ではいろいる
と不便な面が生じるようになって来ている，そこで， 将来局内設備がディジタル化されるときには, コンポ ーネント方式になることは衆目の一致するところであ る。

しかし, 内力設備を全部ディジタル化するのは非常 に経費のかかることでもあり，これが実現するまでに はまだ時間がかかりそうである，そこで，局内設備の ディジタル化が実現するまでの過渡期において, アナ ログコンポーネントを導入することが国外において検 討され始めている.

最初にスタジオ用アナログコンポーネント方式が提 案されたのはヨーロッパからであるが ${ }^{16)}, \mathrm{MAC}$ と似 た形式となっている. 米国でも, SMPTE にアナロ グコンポーネント方式を研究するためのワーキンググ ループ WG-CAVS (Component Analog Video Standard）が設けられて, (i ) 方式, (ii)インタフェー ス, (iii) VTRの3つの項目について検討が進められ ている ${ }^{17)}$.こちらでは, スタジオ用としてはクロマキ 一処理などを含めて線順次色信号では不充分であると して, 同一走查線上に輝度信号と 2 つ色信号を時分 割多重する方式を考えている.また, 輝度信号と色信 号の時間圧縮比は, ディジタルコンポーネント方式と の両立性を考慮して, $4: 2: 2$ の逆比にとっている. このほかに, 従来のコンポジット方式で, 色信号の副 搬送波周波数を $6.7 \mathrm{MHz}$ にとってクロスカラーなど をなくす方式も検討されたが, 周波数多重方式は伝送 路特性維持の嚴しさが残る点で採用されなかった。こ れに反して, 時分割多重方式は, 少々帯域制限されて も輝度信号と色信号の高域が低下するだけで，重大な ひずみを生じない, さらに, 将来エンハンストテレビ などに対して拡張性を持つという利点もある.

CCIR では, 1983 年の中間会議でアナログコンポー ネントに関する新研究計画 $\mathrm{AJ} / 11$ がまとめられてい

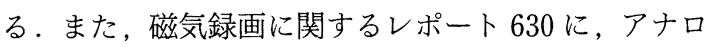
グコンポーネント録画がとりあげられている.

我が国におけるこの方面の動きはあまり活発ではな いが，具体的な動きとしては，アナログコンポーネン 卜方式のカメラ一体型 VTR が開発されたことがあげ られる ${ }^{18)}$. VTR も FM 伝送系であるから, コンポー ネント方式の方が当然有利である.

\section{1 アナログコンポーネント方式のスタジオシス テムへの適合性}

時分割多重アナログコンポーネント方式は，デコー ド(時間伸長)のたびに AD-DA 変換を必要とするか ら，信号処理のたびにデコードをするのは好ましくな い.アナログコンポーネント信号による信号処理を考 
えてみると，調整卓におけるスイッチングやミキシン グは，時分割多重信号のままでできる．むしろ輝度信 号と色信号を独立 3 チャンネルで扱うより回路は簡単 になる。

特殊効果に属するクロマキー, ワイプ, などは, 色 信号を時間伸長して輝度信号と同一時間軸で扱う方が やりやすいが, 輝度信号と色信号の時間圧縮比が簡単 な整数比であれば, 各々別のキー信号を作ることも不 可能ではない.もっとも今後特殊効果の分野はディジ タル専門になって行くだろうから, その場合はデコー ドすればよい.

モニタに関しては，どうしてもデコードが必要にな って来るが，これは信号の主ルートではない。また， 信号の有無や内容判別だけであれば，モノクロモニ夕 に時分割多重信号のまま表示をすれば良い. 特に輝度 信号だけを正常サイズで見たいときは，モニ夕の水平 偏向回路で画面制御を行う。

以上のように, 局内システムにアナログコンポーネ ント方式を用いたとき，主ループではそれほどたびた びデコードのための AD 変換を繰返さなくてもすみ, 画質劣化が問題となることはないであろう. 今後, ア ナログコンポーネント方式が普及して行くかどうか は，ディジタルコンポーネント方式が目に見えている 時に, 過渡期的に導入をはかることによるメリットが 充分あるかどうかにかかることになる．

\subsection{NTSC-コンポーネント変換方式}

前述のように, 今後は NTSC 方式中心の局内設備 の中に, コンポーネント方式が浸透して来て, 相互間 の信号方式変換の機会も増えて行くものと考えられ る.

NTSC 信号をコンポーネント信号へ変換するとき, YC 分離はできるだけ完全に行うことが望ましいが, フレームメモリーを用いた YC 分離により，ほぼこれ を完全に達成することができる．カラーテレビ信号の 周波数スペクトルは, 図 1 に示したような周波数イン タリーブの形になっている。しかし, 画面が斜め方 向の細かい縞模様であると, 図 12(a)のようにサイ
ドバンドが広がり, 色信号成分へクロスカラーを生じ る。このようなクロスカラー成分は，1Hメモリーを 用いたくし形フィルタでは取除くことができない.

ここでテレビ信号のスペクトルの細部に着目する と, 図 12 (a)のように輝度信号は $30 \mathrm{~Hz}$ おきの線ス ペクトルを持ち, 色信号とは, $15 \mathrm{~Hz}$ 間隔でインタリ ーブしていることがわかる．そこで図 12(b)のよう に $30 \mathrm{~Hz}$ 周期のくし形フィル夕を用いれば, 輝度信 号と色信号を完全に分離することができる。これは， 時間軸上でいえば, 相隣る 2 フレームの信号間で加算 あるい減算を行うことに相当し, 減算では輝度成分は 打消し合い．搬送色信号のみが取出せる．当然これか ら考えられるのは, 動画に対してこの方法は無効であ るということであるが, 動画の場合はテレビカメラの 蓄積効果により画面がぼけ，スペクトル中の高域サイ ドバンド成分が低下するので, $1 H$ 型くし形フィル夕 で充分 YC 分離ができるということになる.

フレームメモリーを用いた YC 分離回路の構成を図

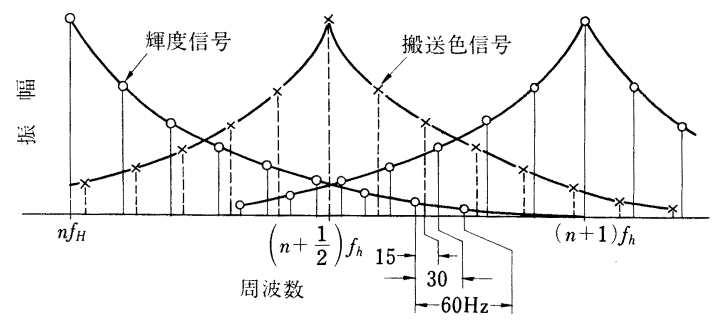

(a) NTSC 信号のスペクトルの細部

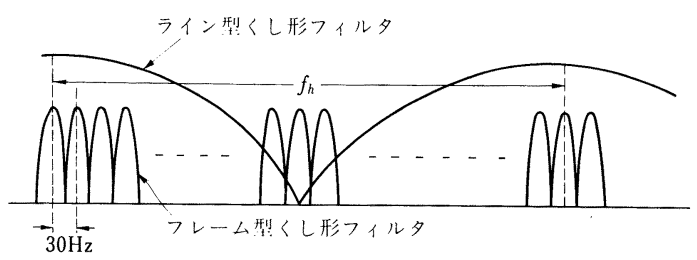

(b) 輝度信号拢出し用くし形フィル夕の特性

図 12 NTSC 信号のフレーム型くし形フィル夕によ る $\mathrm{YC}$ 分離

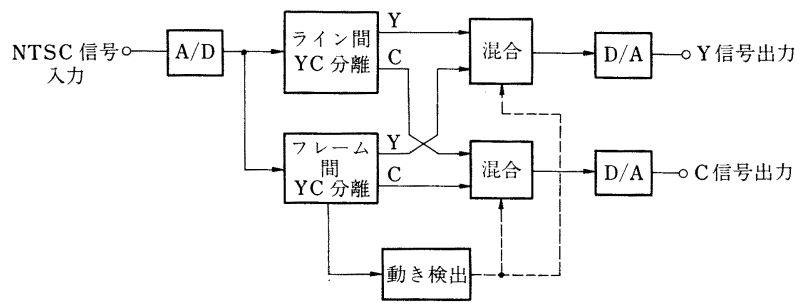

図 13 フレームメモリーを用いた YC 分離回路 
13 に示す ${ }^{19)}$. NTSC 信号は, $1 H$ メリーくし形フ イルタを用いた YC 分離回路と 1 フレームメモリーく し形フィルタを用いた YC 分離回路に並列に加えら れ，別に設けられた動き検出回路により，どちらの出 力を使用するかの選択切替えが行われる.

\section{5.む す び}

アナログコンポーネント方式は，信号処理，記録， 伝送などの分野で NTSC 方式に代わってわずかなが らも使用され始めている。この方式は, 局内システム が全ディジタル化されるまでの過渡的な役割を果たす に過ぎないであろうが，カメラ一体型 VTR に見られ るように, 将来とも特殊な分野ではその特長を発揮し て行くことになろう.また，アナログコンポーネント 方式をすぐ採用することはないにしても，その背後に は NTSC 方式に関する重要な問題提起が含まれてお り, 現行方式の見直し, 改善のために,この一文が読 者の参考になれば筆者の喜びとするところである.

(昭和 59 年 10 月 3 日受付)

\section{〔参 考 文 献〕}

1）“スタジオ用ディジタルテレビ符号化のパラメータ”, CCIR, Rec. 601 (1982)

2）藤尾：“TV 系における評価ノイズ電力の一元化と高品位 TV 伝送系の設計”，信学技報，CS 76-54, pp. 87-94（July， 1976)

3）岩村ほか：“色差信号時間圧縮記録方式とカラー画像再生”, テレビ全大，6-4, p.157（1973）

4）矢野, 湯山：“標準テレビ TCI 信号の衛星 FM 伝送特性の 検討”, テレビ全大， 6-8, pp. 129-130（1984）

5）久保田, 石田：“高品位テレビ TCI 衛星伝送システム”, テ
レビ学技報, ICS 56-4, pp. 55-60（Sep., 1982）

6）久保田, 石田：“コンポーネント符号化における色フィルタ 一の所要特性”, テレビ学技報, TEBS 79-5, pp. 25-30 (Mar., 1982)

7）二宮, 大塚, 和泉：“高品位テレビの衛星 1 チャンネル伝送 方式(MUSE)”, テレビ学技報, TEBS 95-2, PPOE 51-2, pp. 37-42 (Mar., 1984)

8) Lucas, et al: "Direct Television Broadcasts by Satellite: Desirability of New Transmission Standard", IBA E \& D Report, 116, pp. 1-19 (Sept., 1981)

9) Windrum, et al: "MAC-A Television System for HighQuality Satellite Broadcasting”, IBA E \& D Report, 118, pp. 1-40 (Aug., 1982)

10) Oliphant: "An Extended PAL System for High Quality Television”, BBC RD Report, 11, pp. 1-9 (Dec., 1981)

11) Part: "Direct Broadcasting by Satellite: Report of the Advisory Panel on Technical Transmission Standard", Home Office Department of Industry, pp. 1-57 (Nov., 1982)

12) Baldwin: "Colour Television Standard for Satellite Applications", EBU Rev. Tech., 197, pp. 12-19 (Feb., 1983)

13) Windrum, et al: "Extended Definition MAC", IBA E \& D Report, 125, pp. 1-27 (Aug., 1983)

14）西沢, 田中：“フレームメモリーを用いたインターレース走 查画像の順次走查画像への変換”, 信学技報, IE $82-6$, pp. 39-46 (Apr., 1982)

15）佐藤：“衛星テレビジョン放送の音声信号方式”，テレビ誌， 37, 5, pp. 366-374 (May, 1983)

16) Baldwin: "Implementation of the Digital Component Video Standard-A 625 line view”, SMPTE J., 92, 11, pp. 1193-1196 (Nov., 1983)

17) Weiss: "Component Analog Video Standards-A Progress Report”, IBC '84, pp. 48-52 (Sept., 1984)

18）浮ヶ谷, 小川：“テレビジョン年報； $2-1$ 番組制作”, テレビ 誌, 38, 7, pp. 569-576 (July, 1984)

19）藤村ほか：“補間フィルターを用いた走查線変換装置”, 第 14 回画像工学コンファレンス, 8-10 (1983)

\section{テレビジョン学会誌 3 月号予定目次}

【ふお一かす】 地方局とニューメディア……….............................................................静民県民放送 金子 晋

【技 術 解 説】ホームファクシミリ…………………….....................................横須賀通研 旗手喜男・清水俊夫

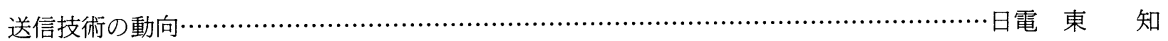

【技 術 の 話 題】 宇宙ステーション……………………………………………....宇宙科学研 長友信人・栗木恭一

【論 文・資 料】適応ディジタルフィルタによる FM マルチひずみ自動除去の一方式

東大 望月孝志・羽鳥光俊

短波放送帯におけるチャンネル容量の推定 ………………………………………HK 戸塚良則

【研 究 速 報】 FFT, WFT アルゴリズムのイデアルによる表現 ……………………………..芝浦工大 松尾 博

【講座】ディジタルテレビジョンの基礎（第 4 回）：IC メモリー……….............................

【現 場 だより】放送大学……………….................................................................放送大学 岡 行輔

中国自動車道千代田地区 CCTV システム…………………………………..道路公団 坂元光政

【会議レポート】第 15 回画像エ学コンファレンス …………………………………………横須賀通研 鎧沢 勇

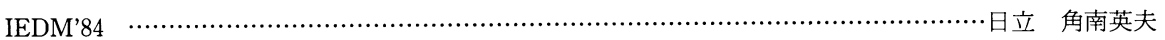

第 21 回 $\mathrm{ABU}$ 技術委員会……………………………………………………NHK 益子 豊 